\title{
Parasitism in species of Bathymodiolus (Bivalvia: Mytilidae) mussels from deep-sea seep and hydrothermal vents
}

\author{
Megan E. Ward ${ }^{1, *}$, Jeffrey D. Shields ${ }^{2}$, Cindy L. Van Dover ${ }^{1}$ \\ ${ }^{1}$ Department of Biology, The College of William \& Mary, Williamsburg, Virginia 23185, USA \\ ${ }^{2}$ Virginia Institute of Marine Science, The College of William \& Mary, Gloucester Point, Virginia 23062, USA
}

\begin{abstract}
Bivalve species, especially mussels, are biomass dominants in many deep-sea chemosynthetic ecosystems. As in shallow-water environments, parasites are likely to be important factors in the population dynamics of bivalve communities in chemosynthetic ecosystems, but there has been little study of parasitism in deep-sea seep or vent molluscs. In this study, parasite types, diversity, prevalence, infection density and non-infectious indicators of stress or disease as related to host age, reproductive condition, and endosymbiont density were assessed in mussels (Bathymodiolus heckerae) from 2 seep sites and mussels (B. puteoserpentis) from 2 vent sites. We identified 10 microbial or parasitic agents in histological sections. Parasite types included 3 viral-like gut inclusions, 2 rickettsia-like gill inclusions, a rickettsia-like mantle inclusion, a bacterial gill-rosette, a chlamydia-like gut inclusion, gill-dwelling ciliates, and an unidentified inclusion in gut tissues. Parasite species richness was greater in seep mussels than in vent mussels, with the seep mussels possessing 9 types of parasites compared to 2 in the vent mussels. One of the viral-like inclusions infecting the seep mussel $B$. heckerae was pathogenic, causing lysis of the digestive tubules. The prevalence and intensity of infection by this pathogen were greater in hosts with shell lengths less than $100 \mathrm{~mm}$. Mussels from all 4 sites also exhibited intense infiltration of tissues and blood spaces by enlarged hemocytes. Hemocytic infiltration (hemocytosis) showed variable degrees of severity that were not associated with other host factors examined.
\end{abstract}

KEY WORDS: Chemosynthetic ecosystems $\cdot$ Mollusc $\cdot$ Virus $\cdot$ Pathogenicity $\cdot$ Community ecology Parasite ecology $\cdot$ Endosymbiotic bacteria $\cdot$ Commensal polychaetes

\section{INTRODUCTION}

Parasitic infections can impair growth, reproduction, competitive ability, stress tolerance and survival of host species (Kautsky 1982, Price et al. 1986, Esch et al. 1990, Calvo-Ugarteburu \& McQuaid 1998). In addition, parasites may regulate host population structure and influence coexisting species, such as the host's prey, predators or competitors (Anderson 1978, Anderson \& May 1978, Price et al. 1986, Calvo-Ugarteburu \& McQuaid 1998). Parasitism is thus an important factor to consider in studies of the ecology and dynamics of populations within any ecosystem (Esch at al. 1990, Powell at al. 1999, Montaudouin et al. 2000). The paucity of studies of parasitism in organisms living in bathyal environments is a consequence of both the relative inaccessibility of the deep sea and the low biomass and abundance of the organisms living there. Chemosynthetic environments (hydrothermal vents and cold seeps) in the deep sea are celebrated for the high biomass and abundance of organisms adapted for life under extreme conditions, yet surprisingly little is known about parasitism in organisms living in these environments.

Hydrothermal vents are submarine hot springs located along mid-ocean ridges. They are dynamic, ephemeral ecosystems characterized by metal-rich fluids and temperatures elevated above those of the 
ambient deep sea (see Van Dover 2000). Deep-sea seeps are located primarily on continental margins where reduced compounds diffuse from the sea floor into the overlying water column. Seeps occur in a variety of settings (Sibuet \& Olu 1998) and include petroleum seeps, which are common in the Gulf of Mexico (MacDonald et al. 1990), brine seeps found on the Florida Escarpment (Paull et al. 1984), and gas-hydrate seeps, including the methane-hydrate seep at Blake Ridge, off the coast of South Carolina (Van Dover et al. 2003). In contrast to hydrothermal vents, seeps are thought to be more stable, longer-lived ecosystems (Sibuet \& Olu 1998). Ecological studies in these environments are still in their infancy and investigations of parasite burdens, pathology and disease in species living at seeps and vents are scarce.

Bathymodiolin mussels (Mytilidae) are one of the dominant megafaunal taxa found at seeps and vents. Bathymodiolin mussels at vents typically live in water between 5 and $15^{\circ} \mathrm{C}$ (Van Dover 2000); mussels at seeps are generally present at ambient seawater temperatures $\left(\sim 2^{\circ} \mathrm{C}_{i}\right.$ Sibuet \& Olu 1998). Mussels play key roles in seep and vent ecosystems: they serve as physical habitats for other invertebrates, and they house chemoautotrophic, endosymbiotic bacteria within gill epithelial cells, called bacteriocytes (Cavanaugh 1983, Le Pennec \& Hily 1984). The endosymbionts account for a large proportion of the primary production in seep and vent communities. The energy required for carbon dioxide fixation is obtained by oxidation of reduced compounds in the endosymbionts; fixed carbon is translocated to the host mussel (Cavanaugh 1983). Bathymodiolin mussels can obtain nutrition from single (e.g. thiotrophic bacteria) or dual (e.g. thiotrophic and methanotrophic bacteria) symbioses. Healthy mussels retain a functional gut and an ability to filterfeed on particulate organic matter (Le Pennec et al. 1990), but in the absence of reduced compounds, gill condition deteriorates (Raulfs et al. in press).

Although diseases of commercially valuable intertidal bivalves have been extensively studied, little is known about parasites in bivalves found at deep-sea seeps, and nothing is known of parasites in bivalves found at hydrothermal vents. Extreme conditions in chemosynthetic ecosystems include high concentrations of metals at vents, brines and hydrocarbons at some seeps, and sulfide-rich effluents or pore-waters. Organisms endemic to chemosynthetic environments have adapted to these environments and require what would normally be considered noxious conditions.

Powell et al. (1999) examined the relationship between elevated concentrations of polycyclic aromatic hydrocarbons (PAH) and parasite burdens in mussels Bathymodiolus sp., from 4 hydrocarbon seep sites in the Gulf of Mexico (depth 550 to $650 \mathrm{~m}$ ). In coastal mussels, PAHs disrupt membranes, damage lysozymes and inhibit hemocyte phagocytic ability (Pipe \& Coles 1995, Fernley et al. 2000). Unlike shallow-water mussels, the mussels from hydrocarbon seeps were obligately associated with high PAH concentrations; 5 types of parasites were documented in the hydrocarbonseep mussels, including extracellular gill ciliates, bacterial gill rosettes, Bucephalus-like trematodes, and chlamydia/rickettsia-like gill and gut inclusions (Powell et al. 1999). In comparison to mussels from intertidal sites, the mussels from hydrocarbon seeps had similar types of parasites, but were more heavily parasitized. Infections of Bucephalus-like trematodes caused severe castration of hydrocarbon-seep mussels, leaving $40 \%$ of the populations in the study reproductively compromised (Powell et al. 1999).

To explore further the relationship between parasite burdens in bathymodiolin mussels and chemosynthetic environments, we conducted a comparative study of parasite burdens in Bathymodiolus heckerae from 2 deep-sea seeps and B. puteoserpentis from 2 deep-sea hydrothermal vents. Both species contain methanotrophic and thiotrophic endosymbiotic bacteria. Differences in types of parasites and abundance of parasites were documented between the 2 geologically and ecologically distinct habitat types. Prevalence, infection densities, and noninfectious indicators of stress or disease as they related to age, reproductive condition and an index of endosymbiont density were also assessed.

\section{MATERIALS AND METHODS}

Specimens of Bathymodiolus heckerae were collected using the deep-sea submersible 'Alvin' from 2 seep sites: a cold-water, saline site at the Florida Escarpment $\left(26^{\circ} 2^{\prime} \mathrm{N}, 84^{\circ} 55^{\prime} \mathrm{W}, 3300 \mathrm{~m}\right.$; sampled in October 2000) and a gas-hydrate site off the Carolina coast (Fig. 1; Blake Ridge 32 ${ }^{\circ} 31^{\prime}$ N, 76 $12^{\prime}$ W, 2155 m; sampled in September 2001). Species of B. puteoserpentis were collected from the Logatchev vent $\left(15^{\circ} 45^{\prime} \mathrm{N}, 44^{\circ} 58^{\prime} \mathrm{W}, 3300 \mathrm{~m}\right.$, sampled in July 2001;

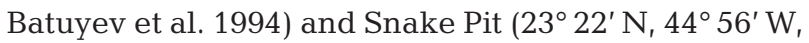
3600 m, sampled in July 2001; Karson \& Brown 1988).

Mussels were sorted by length, and 30 to 32 specimens were systematically selected to represent an even distribution across the range of sizes available. Shell lengths were recorded for each specimen. Within $3 \mathrm{~h}$ of collection, mussels were removed from the shell, tagged, fixed in Davidson's solution (Humason 1972) for $24 \mathrm{~h}$, and stored in $70 \%$ ethanol. The number and lengths of commensal polychaetes Branchipolynoe seepensis in the mantle cavities of the mussels were determined. 


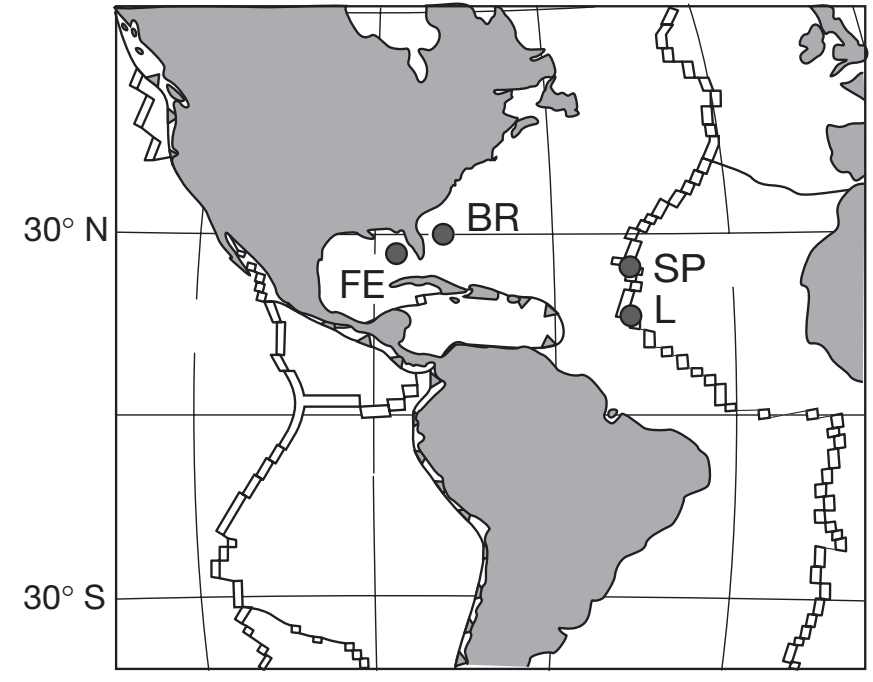

Fig. 1. Locations of Florida Escarpment (FE) and Blake Ridge (BR) seep sites and Logatchev (L) and Snake Pit (SP) vent sites

Wet weight was determined for whole, fixed mussels without the shell. An oblique, $\sim 5 \mathrm{~mm}$ thick, transverse tissue slice, containing mantle, gonad, digestive tract and gill was dissected from each specimen. This tissue slice was dehydrated in a graded ethanol series, embedded in paraffin, and transverse sections were taken at 5 to $6 \mu \mathrm{m}$. Sections were stained with Gill's hematoxylin and eosin (H\&E; Stevens 1990) or Ordway-Machiavello for rickettsia (Humason 1972) to identify parasite types and prevalence (no. of host individuals infected with any parasite; Margolis et al. 1982) using light microscopy. A Spot camera (Diagnostic Instruments) was used for capturing images for light microscopy. Contrasts were adjusted and photomosaics were generated using Adobe Photoshop (Adobe Systems).

Using an ocular grid, parasite densities (number of parasites per area standardized to $500 \mu^{2}$ of tissue; Margolis et al. 1982) were determined for infected individuals. We examined 5 grids per section for 3 sections that were separated by $\sim 1 \mathrm{~mm}$ or more. Body burden (mean infection densities for all parasitic infections) of infected individuals was also determined. A quantitative measure of bacterial endosymbiont density was determined for Bathymodiolus puteoserpentis by measuring the area of the gill bacteriocytes occupied by the endosymbiotic bacteria to derive a ratio of the area occupied by the endosymbiotic bacteria to the area of the gill bacteriocytes. Cells used to measure bacterial endosymbiont density were located on sections of the transverse gill filaments in approximately the same region of each mussel. Host sex and gonad stage were measured. Semi-quantitative scales were assigned for intensity of hemocyte infiltration
Table 1. Index used to determine intensity of hemocyte infiltration in Bathymodiolus spp.

\begin{tabular}{|c|c|}
\hline Intensity & Description \\
\hline 0 & No areas of infiltration \\
\hline 1 & $\begin{array}{l}\text { Slight infiltration, small, focal, usually only around } \\
\text { intestine }\end{array}$ \\
\hline 2 & $\begin{array}{l}\text { Several small foci of infiltration or a few larger areas; } \\
\text { sometimes in more than } 1 \text { type of tissue }\end{array}$ \\
\hline 3 & $\begin{array}{l}\text { Disseminating foci ranging from small to large areas; } \\
\text { infiltration extensive and usually in several or all } \\
\text { types of tissue }\end{array}$ \\
\hline 4 & $\begin{array}{l}\text { A few blood vessels enlarged due to heavy infiltration } \\
\text { of hemocytes }\end{array}$ \\
\hline 5 & $\begin{array}{l}\text { Most blood vessels enlarged due to massive } \\
\text { infiltration }\end{array}$ \\
\hline
\end{tabular}

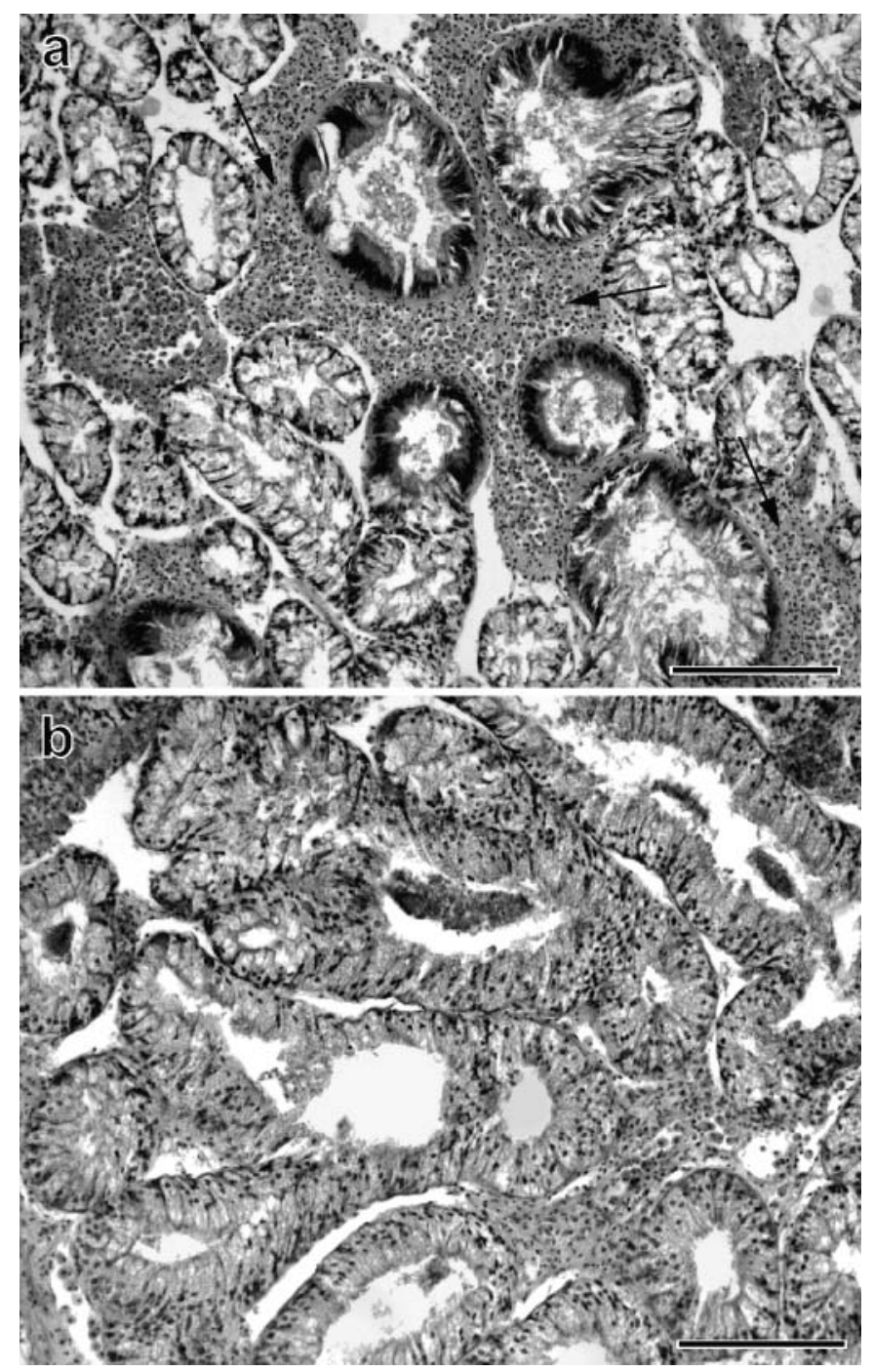

Fig. 2. Bathymodiolus puteoserpentis. Hemocyte infiltration. (a) Heavy infiltration of hemocytes (arrows) around digestive diverticula and intestine; (b) healthy visceral mass tissue without hemocyte infiltration. Scale bars $=200 \mu \mathrm{m}$ 
Table 2. Index used to determine gonad development in Bathymodiolus spp.

\begin{tabular}{|cl|}
\hline Gonad stage & \multicolumn{1}{c|}{ Description } \\
\hline 1 & $\begin{array}{l}\text { Undifferentiated; few areas in visceral mass } \\
\text { with gonad }\end{array}$ \\
2 & $\begin{array}{l}\text { Early stages of developing gametes; several } \\
\text { areas of visceral mass with small regions of } \\
\text { gonadal development }\end{array}$ \\
3 & $\begin{array}{l}\text { Approximately equal proportions of devel- } \\
\text { oping and mature gametes; large areas of } \\
\text { visceral mass taken up by gonads } \\
\text { Early stages of gametogenesis rare; follicles } \\
\text { contain mature gametes; visceral mass } \\
\text { densely packed with gonad }\end{array}$ \\
&
\end{tabular}

per cross-section (Table 1, Fig. 2) and density and stage of development of gonads (Table 2).

Statistical tests were performed using MINITAB software, Version 13.20, 2000. Comparisons of means among sites were determined using Kruskal-Wallis 1 -way analysis of variance. If significant results $(p<$ 0.05 ) were obtained, ANOVA and Tukey's pairwise comparisons were used to evaluate significant differences among sample pairs. Multi-dimensional scaling (MDS; PRIMER v5; Clarke \& Gorley 2001) was used to examine similarities among individuals based on the parasite type-density matrix, using Bray-Curtis coefficients calculated from non-transformed data. The 16 individuals not infected by any parasite were excluded from the MDS analysis. MDS plots position individuals on a unitless 2-dimensional map; closely spaced points represent the most similar individuals in a multivariate space based on parasite types and density. Analysis of similarity (ANOSIM subroutine of PRIMER v5) was used to determine significant differences between groups of individuals evident in MDS plots. ANOSIM provides R statistics: when $\mathrm{R}>0.75$, groups are well-separated; when $0.75>R>0.5$, groups are overlapping but clearly different; when $\mathrm{R}<0.25$, groups are not separable (Clarke \& Gorley 2001). Factors contributing to these differences of parasite infection densities were determined from similarity percentages (SIMPER subroutine in PRIMER v5). The Shannon-Wiener diversity index $\left(H_{\log (e)}^{\prime}\right)$ was calculated using the DIVERSE subroutine in PRIMER v5. This diversity index takes into account both species richness (the number of parasite types) and evenness (the distribution of individuals among species; Hayek \& Buzas 1997).

\section{RESULTS}

\section{Parasite fauna}

We identified 10 types of parasites (9 in Bathymodiolus heckerae, 2 in B. puteoserpentis) in histological sections: 3 viral-like inclusions in the gut, 2 rickettsialike inclusions in the gill, rickettsia-like inclusions in the mantle, bacterial rosettes in the gill, chlamydia-like inclusions in the gut, gill ciliates and an unidentified inclusion in the gut.

One of the viral-like inclusions in the gut, referred to hereafter as Viral Inclusion I, was observed only in the vent mussel Bathymodiolus puteoserpentis, where it occurred in the digestive diverticula (Fig. 3a). These eosinophilic inclusions were generally spherical in shape with an average diameter of $20 \mu \mathrm{m}(\mathrm{n}=20$; Fig. 3b). Occasionally, the cell contents were peripherally located in the host cell or the cell was hypertrophied (Fig. 3b).

In the gut, 2 viral-like inclusions were associated with the seep mussel Bathymodiolus heckerae. Of these, one, hereafter referred to as Viral Inclusion II, occurred in the nuclei of stomach and intestinal epithelia of mussels from the Florida Escarpment (Fig. 3c). The inclusion had a waxy, eosinophilic appearance and was oval or spherical in shape with an average diameter of $11 \mu \mathrm{m}(\mathrm{n}=20)$. The inclusion was surrounded by what we infer to be the hypertrophied nuclear envelope of the host cell. Lighter staining rings were occasionally visible within the inclusion (Fig. 3d). No obvious tissue pathology was associated with this infection.

A third viral-like inclusion in the gut (Viral Inclusion III), infected the epithelial nuclei of the digestive diver-

Fig. 3. Bathymodiolus spp. containing viral-like inclusions. (a) Individual heavily infected with Viral Inclusion I in digestive diverticula; scale bar $=200 \mu \mathrm{m}$. (b) Viral Inclusion I in digestive diverticula causing hypertrophy and necrosis of the host cell ( $*$ ); scale bar $=20 \mu \mathrm{m}$. (c) Viral Inclusion II infecting stomach epithelial cells; scale bar $=50 \mu \mathrm{m}$. (d) Detail of Viral Inclusion II showing hypertrophied nuclear envelope (arrow); scale bar $=10 \mu \mathrm{m}$. (e) Viral Inclusion III infecting digestive diverticula and intestinal tissue; viral-like inclusion bodies visible in lumen and tissues with necrotic areas of digestive diverticula (arrowheads); scale bar = $200 \mu \mathrm{m}$. (f) Viral Inclusion III within 2 tubules of the digestive diverticula; scale bar $=10 \mu \mathrm{m}$. (g) Digestive diverticula infected with Viral Inclusion III with necrotic tissue caused by the virus; mass of viral-like inclusions and necrotic cells are visible in 1 tubule (asterisk); scale bar $=60 \mu \mathrm{m}$. (h) Uninfected digestive diverticula for comparison; scale bar $=50 \mu \mathrm{m}$. bm: basement membrane; dd: digestive diverticula; l: lumen; ne: nuclear envelope; nu: nucleus; s: stomach; vi I: Viral Inclusion I; vi II: Viral Inclusion II; vi III: Viral Inclusion III 

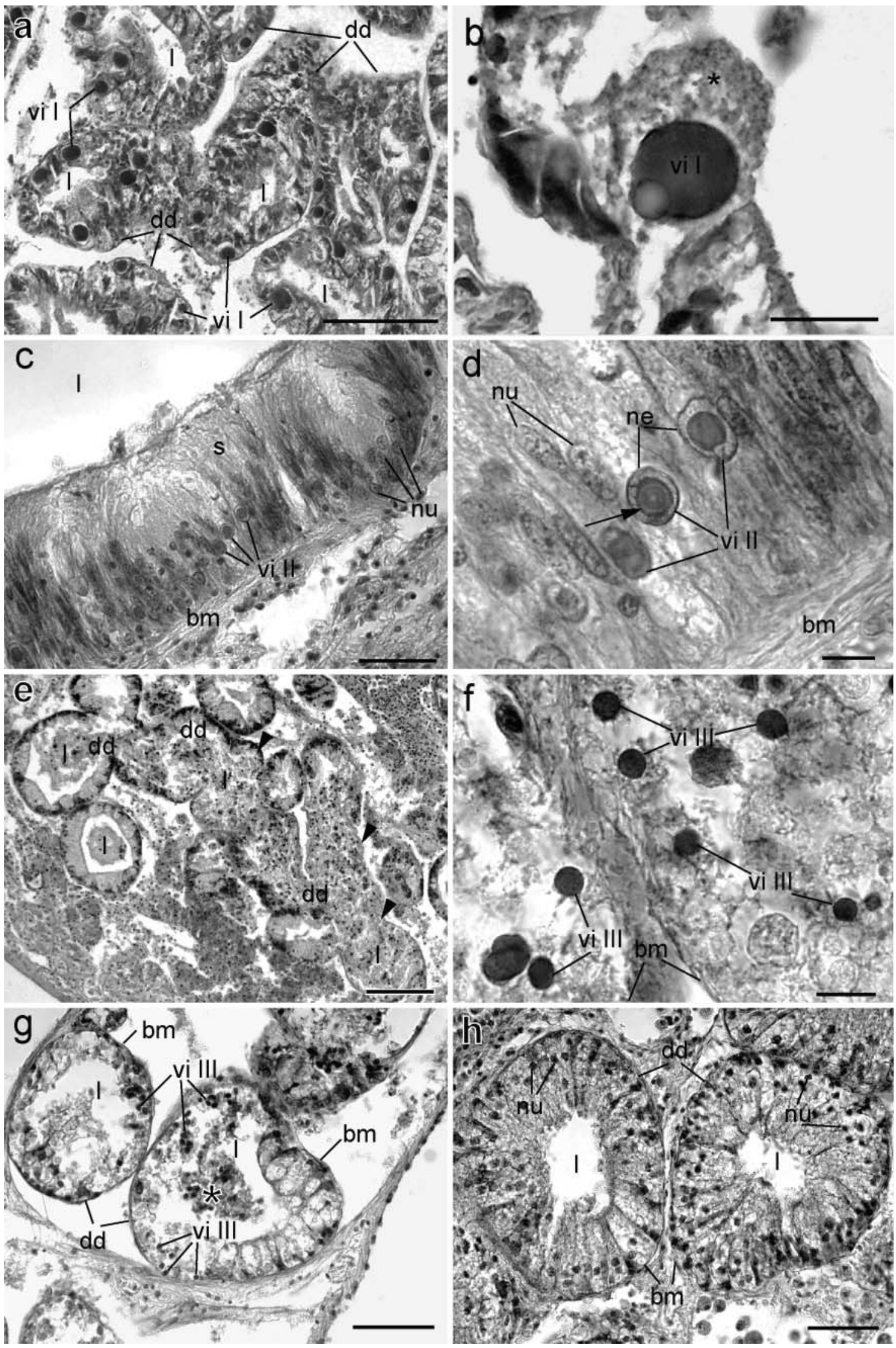
ticula and intestines of Bathymodiolus heckerae from both seep sites (Fig. 3e). Infections were characterized by small $(4.8 \mu \mathrm{m}$ diameter; $\mathrm{n}=25)$ eosinophilic spherical bodies within host cells, free in the lumen of the digestive tract (Fig. 3e,f), or occasionally in the connective tissue of the visceral mass. The spherical bodies showed no internal structure at the level of light microscopy. Severe tissue pathology was often associated with infection by Viral Inclusion III (Fig. 3e,f,g). In moderately or heavily infected mussels, infected cells had either lysed or had sloughed into the lumen of the digestive tubules (Fig. 3g). Widespread necrosis of the digestive tissue was evident with large regions of the digestive tissue destroyed, leaving a mass of viral inclusions among the remnants of the cells (Fig. 3e,f). In adjacent healthy mussel tissues, nuclei were basally located and individual cells were easily distinguishable (Fig. 3h).

One of the rickettsia-like inclusions in the gill, referred to as Gill Rickettsia I, was found in both mussel species from all 4 sites. These basophilic, intracytoplasmic inclusions were spherical, with an average diameter of $20 \mu \mathrm{m}(\mathrm{n}=20)$ and could be found in all cell types along the entire length of the gill filament (Fig. 4a,b). Many inclusions had a filamentous internal structure (Fig. 4b) while other inclusions appeared smooth.

A second type of rickettsia-like inclusion in the gill, referred to as Gill Rickettsia II was found only in Bathymodiolus heckerae from the Florida Escarpment. The intracytoplasmic inclusions were basophilic and were found along the entire length of the gill filament within the host bacteriocytes (Fig. 4c). These inclusions were morphologically different from Gill Rickettsia I, being larger (average diameter $37 \mu m_{i} \mathrm{n}=20$ ) and more irregular in shape (Fig. 4c,d). These inclusions also had a filamentous internal structure (Fig. 4d). Both types of Gill Rickettsia were capable of displacing the endosymbiotic bacteria to the periphery of the host cell.

The third type of rickettsia-like inclusion, referred to as Mantle Rickettsia, was found in the cytoplasm of mantle epithelial cells in Bathymodiolus heckerae. These inclusions were morphologically similar to Gill Rickettsia I, but due to their different location within the host, they were considered a different parasite. No obvious tissue pathology was observed for this parasite.

Bacterial gill rosettes similar to those described by Powell et al. (1999) were observed in bacteriocytes. They were associated with the host bacteriocytes of Bathymodiolus heckerae, averaged $9 \mu \mathrm{m}(\mathrm{n}=15)$ in diameter, and were located within or penetrating the membrane of the host gill cell (Fig. 4e). The rosette structures were composed of groups of 30 or more basophilic, spherical bodies, each with an average diameter of $2.8 \mu \mathrm{m}(\mathrm{n}=25$; Fig. $4 \mathrm{f})$. No tissue damage was observed except where rosettes penetrated the gill cell membranes.

Chlamydia-like intracytoplasmic inclusions occurred in epithelial cells of the stomach, intestine, and digestive diverticula of Bathymodiolus heckerae. These parasites were basophilic, finely granular, and irregular in shape and size (average diameter $50 \mu m_{;} n=20$ ). The finely granular inclusions appeared either tightly compacted (Fig. 4g) or diffuse (Fig. 4h). Host cells were hypertrophied or lysed by the inclusion (Fig. $4 \mathrm{~g}, \mathrm{~h}$ ).

Ciliates were found among the gills of Bathymodiolus heckerae (Fig. 5a). They had an average length of $30 \mu \mathrm{m}(\mathrm{n}=15)$ and were associated with, but did not appear to be attached to, the gill filaments of the host mussel (Fig. 5a). No obvious tissue pathology was observed.

An unidentified parasite occurred only in Bathymodiolus heckerae. It was characterized by a slightly refringent, intracytoplasmic, basophilic, spherical inclusion with an average diameter of $8 \mu \mathrm{m}(\mathrm{n}=10$; Fig. 5b). These inclusions were located in the epithelial cells of the intestine and digestive diverticula of the host. With the exception of a slight hypertrophy of the host cell, no obvious tissue pathology was observed.

\section{Polychaetes}

Commensal polynoid polychaetes Branchipolynoe seepensis were retained between the gill filaments of 2 vent mussels and subsequently sectioned (Fig. 6a). Displacement of gill filaments and some physical trauma of the filaments resulting in necrosis or poor

Fig. 4. Bathymodiolus spp. with bacteria-like infections. (a) Moderate infection with Gill Rickettsia I; rickettsial inclusions are located in gill bacteriocytes; scale bar $=50 \mu \mathrm{m}$. (b) Gill Rickettsia I with filamentous internal structure; scale bar $=10 \mu \mathrm{m}$. (c) Gill filament infected with both Gill Rickettsia I and Gill Rickettsia II; note difference in size and shape of the 2 inclusions; scale bar = $30 \mu \mathrm{m}$. (d) Gill Rickettsia II with filamentous internal structure and irregular shape; scale bar $=20 \mu \mathrm{m}$. (e) Gill rosettes located among bacteriocytes of host gill filament; gill rosette appears to be breaking through the host gill cell (arrowhead); scale bar = $30 \mu \mathrm{m}$. (f) Gill rosette composed of several spherical bodies with average diameter of $2.8 \mu \mathrm{m}$; scale bar $=10 \mu \mathrm{m}$. (g) Tightly compacted chlamydia-like inclusion in the digestive diverticula; scale bar $=40 \mu \mathrm{m} ;(\mathrm{h})$ More diffuse chlamydia-like inclusion in intestine; scale bar $=40 \mu \mathrm{m}$. bc: bacteriocytes; bm: basement membrane; ch: chlamydia-like inclusion; dd: digestive diverticula; gf: gill filament; gr: gill rosette; i: intestine; 1: lumen; ri I: Gill Rickettsia I; ri II: Gill Rickettsia II 

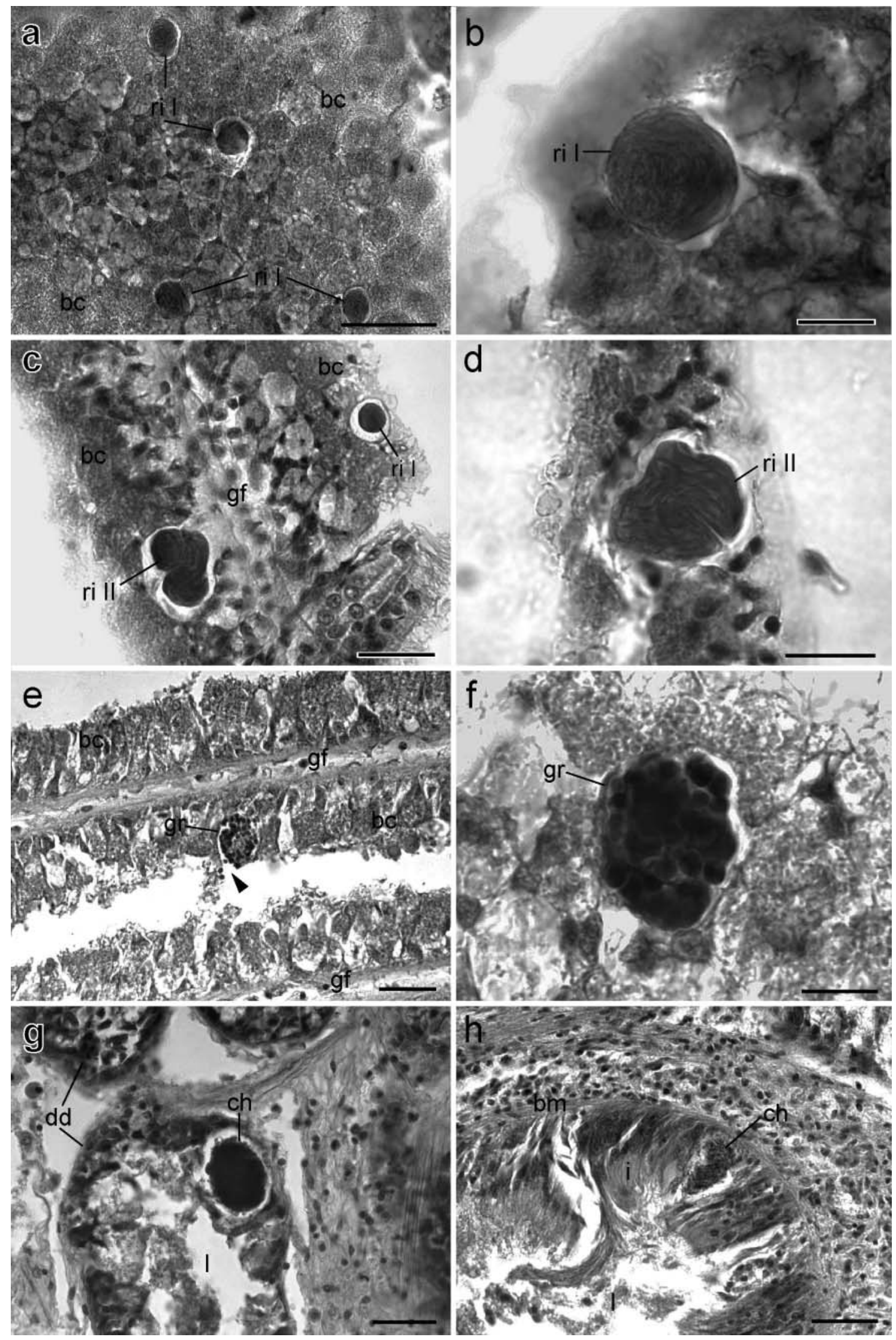


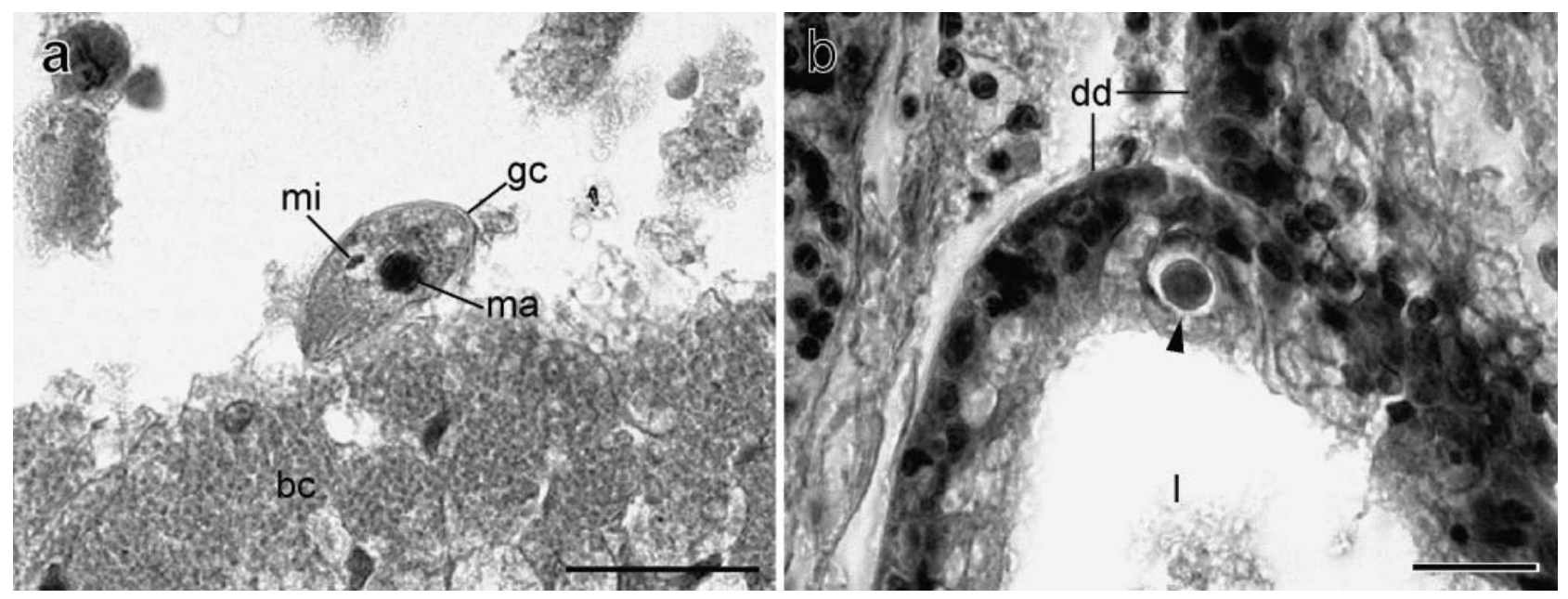

Fig. 5. Bathymodiolus spp. containing gill ciliates and an unidentified parasite. (a) Gill ciliate showing micro- and macro-nucleus; scale bar $=30 \mu \mathrm{m}$. (b) Unidentified intracytoplasmic inclusion (arrowhead) in a digestive diverticulum; scale bar $=20 \mu \mathrm{m}$. bc: bacteriocytes; dd: digestive diverticula; gc: gill ciliate; l: lumen; ma: macro-nucleus; mi: micro-nucleus
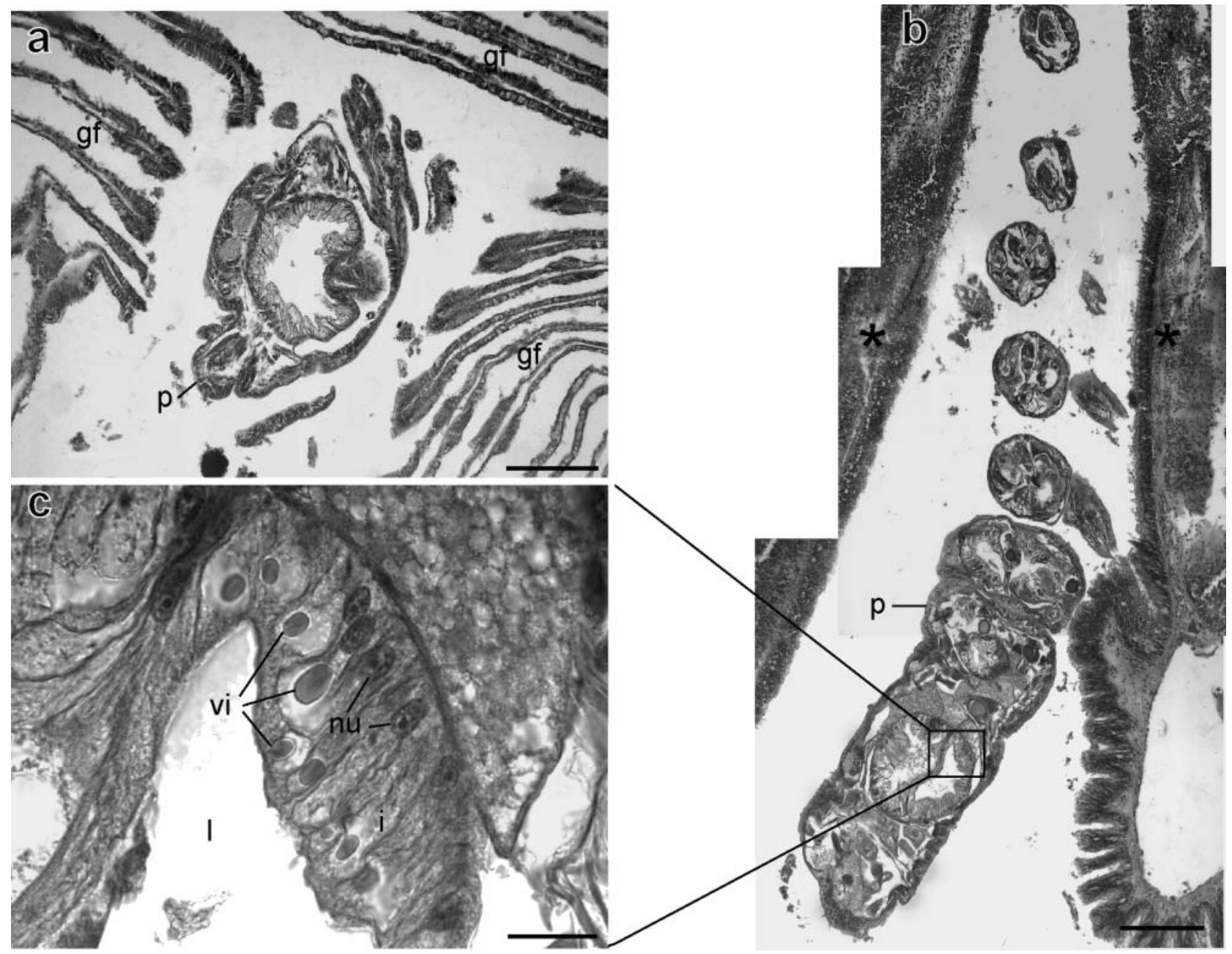

Fig. 6. Bathymodiolus spp. containing commensal polychaetes. (a) Polynoid polychaete Branchipolynoe seepensis between gill filaments of vent mussel B. puteoserpentis; scale bar $=200 \mu \mathrm{m}$. (b) Nautiliniellid polychaete between demibranchs ( $*$ ) of $B$. heckerae from Florida Escarpment; scale bar $=200 \mu \mathrm{m}$. (c) Viral-like inclusions in intestine of the nautiliniellid; scale bar $=20 \mu \mathrm{m}$. gf: gill filaments; i: intestine; l: lumen; nu: nucleus; p: polychaete; vi: viral-like inclusion 
condition were attributed to the polychaetes. In Bathymodiolus puteoserpentis, the commensal polychaete had a prevalence of 30 to $40 \%$. An even greater prevalence of the commensal polychaete was observed in $B$. heckerae from the Florida Escarpment seep site (>60\%). Branchipolynoe seepensis was not observed in $B$. heckerae from the Blake Ridge seep.

In 3 Bathymodiolus heckerae from the Florida Escarpment, 4 nautiliniellid polychaetes (possibly Laubierus mucronatus based on characteristics of the setae) were observed in section (Fig. 6b). The polychaetes were located between the ascending and descending filaments of the demibranchs. Little evidence of damage on the surrounding filaments was observed, although cells in the adjacent gill tissue were detached from the filament or the tissue was in poor condition; 3 of the polychaetes were infected with viral-like inclusions in the digestive tract (Fig. 6c).

\section{Parasite diversity and abundance}

Parasite diversity $\left(H^{\prime}\right)$ was highest $\left(H^{\prime}=0.92\right)$ in Bathymodiolus heckerae from the Florida Escarpment (Table 3). Parasite diversities at the other 3 sites were considerably lower, with $H^{\prime}$ values of $<0.20$. Species richness (number of parasite types) was greater in $B$. heckerae than in B. puteoserpentis (Table 3, Fig. 7a). Mussels from the Florida Escarpment were infected with 9 different types of parasites and $B$. heckerae from the Blake Ridge were infected with a subset of at least 6 of these. Viral Inclusion I was unique to B. puteoserpentis at the vents. Gill Rickettsia I was observed in both mussel species at all 4 sites.

The number of parasite types in infected individuals (Fig. 7b) was species- and site-dependent. Bathymodiolus heckerae from Florida Escarpment seeps had $\sim 4$ times more parasites per individual on average than did $B$. heckerae from Blake Ridge (Kruskal-Wallis: $\mathrm{p}<0.001)$. Infected individuals of $B$. puteoserpentis from the Logatchev vent had a slightly but significantly greater number of parasites per individuals on average (Fig. 7b) than did infected individuals from Snake Pit (1.1; Kruskal-Wallis: $\mathrm{p}=0.017$ ).

More than $70 \%$ of the mussels sampled from all 4 sites were parasitized by 1 or more types of parasites. At the Florida Escarpment site, $100 \%$ of the mussels were infected with at least 1 type of parasite (Table 3, Fig. 8a). Despite large numbers of infected individuals, total body burdens were relatively low except in

Table 3. Bathymodiolus spp. Prevalence (\% of individuals infected) and densities of infection per $500 \mu^{2}$ of tissue for parasitic agents except viral-like infections and data on polychaete infestations. Number of individuals sampled is shown in parentheses next to site names

\begin{tabular}{|c|c|c|c|c|}
\hline \multirow[t]{2}{*}{ Infection } & \multicolumn{2}{|c|}{$\begin{array}{c}\text { Bathymodiolus heckerae } \\
\text { Seep sites }\end{array}$} & \multicolumn{2}{|c|}{$\begin{array}{c}\text { Bathymodiolus puteoserpentis } \\
\text { Hydrothermal vent sites }\end{array}$} \\
\hline & Florida Escarpment (32) & Blake Ridge (32) & Logatchev (32) & Snake Pit (30) \\
\hline \multicolumn{5}{|l|}{ Gill Rickettsia I } \\
\hline Prevalence & $94 \%$ & $13 \%$ & $87 \%$ & $20 \%$ \\
\hline Density $( \pm \mathrm{SD})$ & $0.3( \pm 0.34)$ & $0.1( \pm 0.09)$ & $1.1( \pm 1.20)$ & $0.06( \pm 0.04)$ \\
\hline \multicolumn{5}{|l|}{ Gill Rickettsia II } \\
\hline Prevalence & $69 \%$ & 0 & 0 & 0 \\
\hline Density ( \pm SD) & $0.3( \pm 0.34)$ & 0 & 0 & 0 \\
\hline \multicolumn{5}{|l|}{ Mantle Rickettsia } \\
\hline Prevalence & $3 \%$ & $3 \%$ & 0 & 0 \\
\hline Density ( $\pm \mathrm{SD})$ & 0.03 & 0.7 & 0 & 0 \\
\hline \multicolumn{5}{|l|}{ Bacterial gill rosette } \\
\hline Prevalence & $34 \%$ & 0 & 0 & 0 \\
\hline Density ( \pm SD) & $0.2( \pm 0.35)$ & 0 & 0 & 0 \\
\hline \multicolumn{5}{|l|}{ Chlamydia-like inclusion } \\
\hline Prevalence & $21 \%$ & $3 \%$ & 0 & 0 \\
\hline Density ( \pm SD) & $0.3( \pm 0.56)$ & 0.25 & 0 & 0 \\
\hline \multicolumn{5}{|l|}{ Gill ciliate } \\
\hline Prevalence & $40 \%$ & $3 \%$ & 0 & 0 \\
\hline Density $( \pm \mathrm{SD})$ & $0.04( \pm 0.05)$ & 0.02 & 0 & 0 \\
\hline \multicolumn{5}{|l|}{ Unidentified gut inclusion } \\
\hline Prevalence & $50 \%$ & $12 \%$ & 0 & 0 \\
\hline Density ( \pm SD) & $0.08( \pm 0.05)$ & $0.03( \pm 0.02)$ & 0 & 0 \\
\hline \multicolumn{5}{|c|}{ Branchiopolynoe seepensis polychaetes } \\
\hline Prevalence & $62 \%$ & 0 & $31 \%$ & $40 \%$ \\
\hline \# polychaetes per individual ( \pm SD) & $1.5( \pm 1.26)$ & 0 & $1.1( \pm 0.55)$ & $1.7( \pm 1.24)$ \\
\hline
\end{tabular}




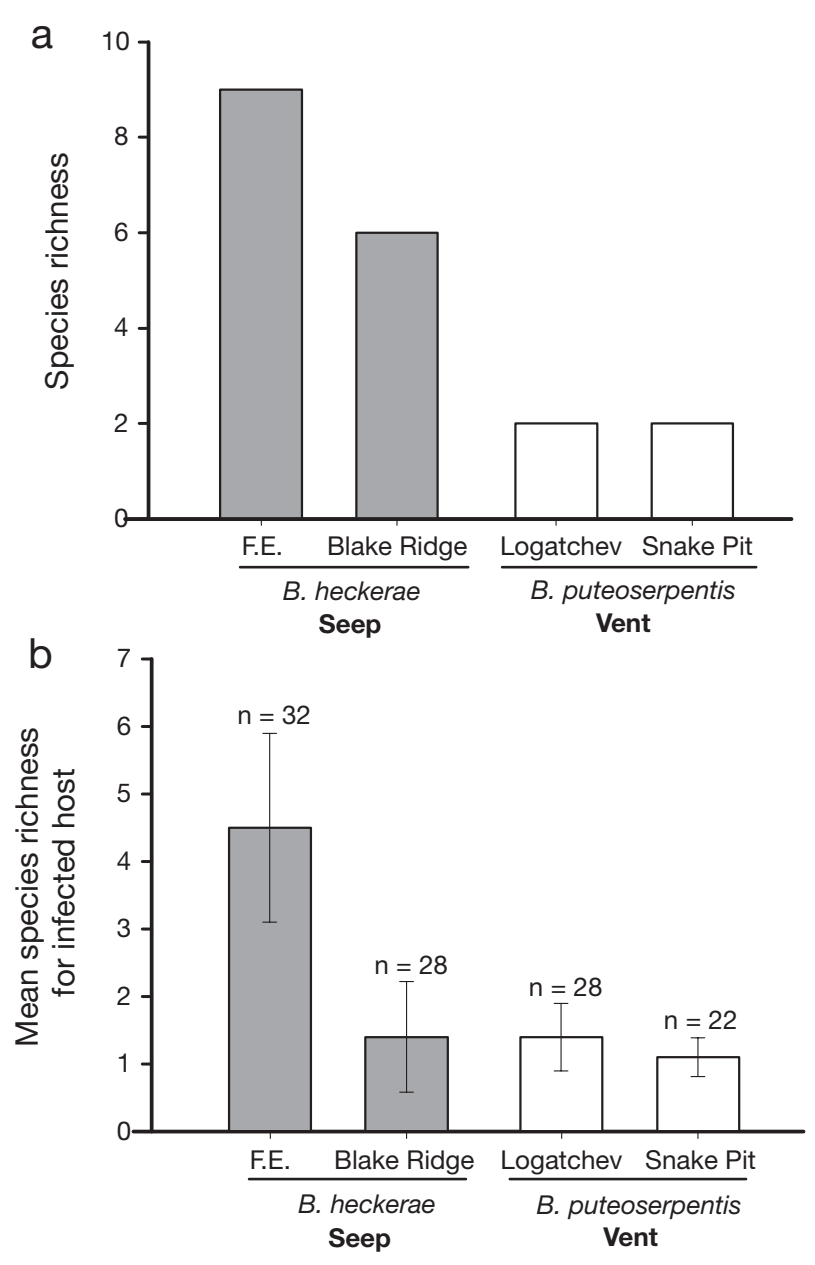

Fig. 7. Bathymodiolus heckerae and B. puteoserpentis (a) Parasite species richness (no. of parasite species) in mussels; (b) mean species richness for infected mussels as a funtion of site. F.E.: Florida Escarpment; n: number of individuals

mussels from the Blake Ridge seep (Tukey's, $\mathrm{p}<0.001$; Fig. 8b). Individuals from the 4 sites were mapped as significantly different groups on MDS plots based on the parasite type-density matrix (Fig. 9; ANOSIM, $\mathrm{R}>0.40$; excluding uninfected hosts). Differences in parasite burdens between Bathymodiolus heckerae and B. puteoserpentis $(\mathrm{R} \geq 0.8)$ and between $B$. heckerae from Florida Escarpment and Blake Ridge $(\mathrm{R}=$ 0.43 ) were attributable to infection by Viral Inclusion III, which accounted for an average of $68 \%$ of the differences (SIMPER). B. heckerae from the Florida Escarpment were mapped into 2 significantly different groups $(\mathrm{R}=0.58$; ANOSIM; Fig. 9). Infection with Viral Inclusion III accounted for $67 \%$ of the difference between these groups (SIMPER). B. heckerae individuals infected with Viral Inclusion III mapped closest to the $B$. heckerae individuals from Blake Ridge that were also infected with the virus (Fig. 9).
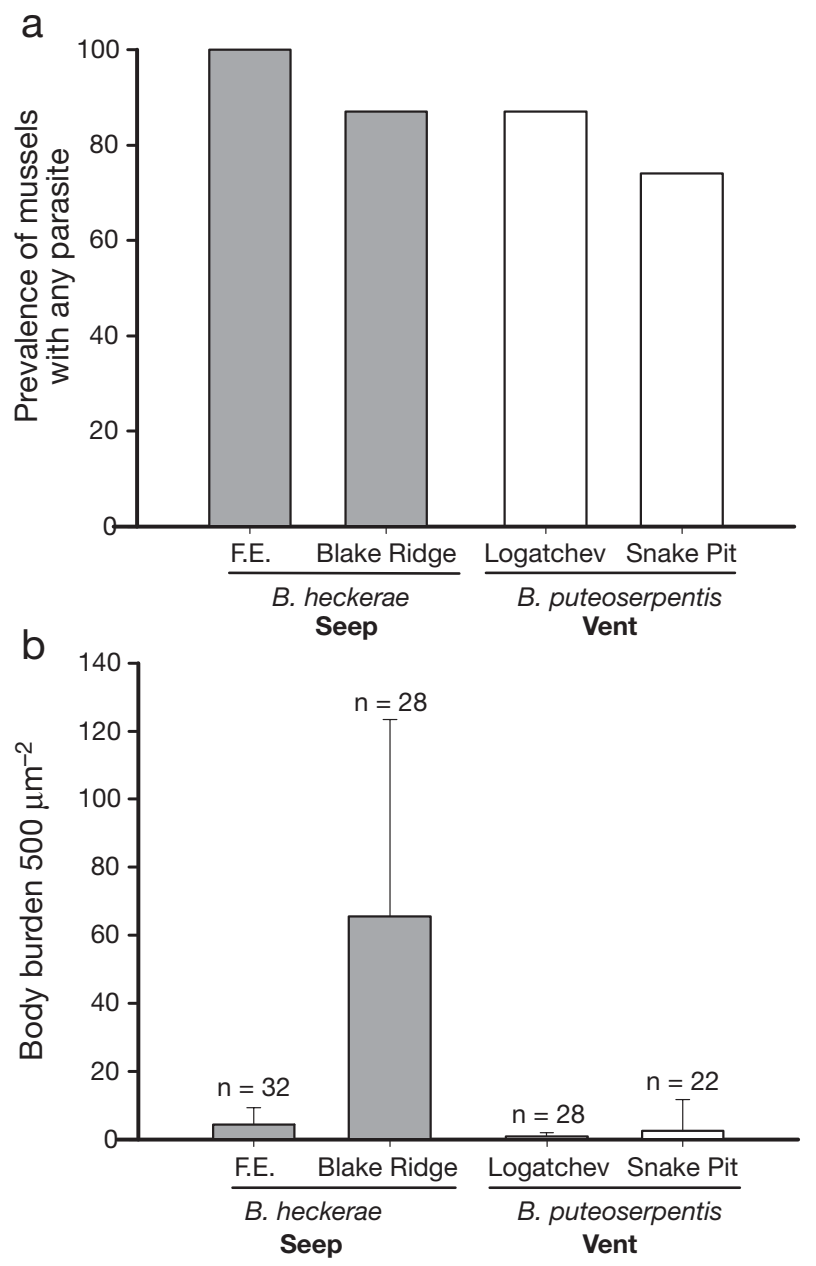

Fig. 8. Bathymodiolus heckerae and B. puteoserpentis. (a) Prevalence of mussels infected with any parasite; (b) body burden (mean infection densities for all parasitic infections) of infected mussels $\left(500 \mu^{-2}\right.$ tissue). F.E.: Florida Escarpment; $\mathrm{n}$ : number of individuals

Viral-like gut inclusions occurred in mussels from all 4 sites, but Bathymodiolus heckerae had a greater prevalence of viral inclusions than $B$. puteoserpentis (Fig. 10a). At Snake Pit, $60 \%$ of B. puteoserpentis were infected with Viral Inclusion I, but $<30 \%$ of the mussels from the Logatchev site were infected with the same or similar Viral Inclusion I. More than $90 \%$ of the B. heckerae from Florida Escarpment were infected with either Viral Inclusion II or Viral Inclusion III; of these, $53 \%$ were infected by both viruses. Almost $90 \%$ of $B$. heckerae from Blake Ridge were infected with the pathogenic Viral Inclusion III. Infection density of Viral Inclusion III was significantly greater in B. heckerae from Blake Ridge than from the Florida Escarpment (Tukey's: $p<0.001$; Fig. 10b). Host size was an important factor in infection of $B$. heckerae. Mean infection density for Viral Inclusion III was greater in individuals with shell lengths $<100 \mathrm{~mm}$ (Kruskal- 


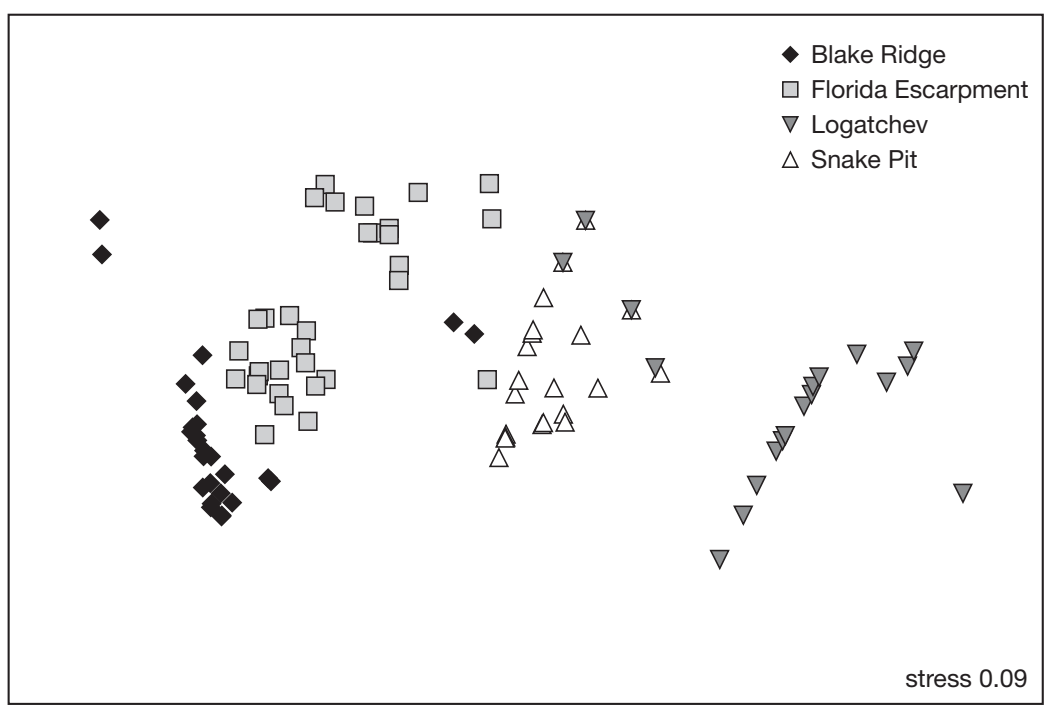

Fig. 9. Bathymodiolus heckerae and B. puteoserpentis. Body burdens of all mussels infected with at least 1 parasite, analyzed by MDS. Samples were placed on a unitless map and distances between samples represent dissimilarity in parasite types and abundance infecting individual hosts $(B$. heckerae $=$ Florida Escarpment and Blake Ridge; B. puteoserpentis = Logatchev and Snake Pit). Note separation between sites
Wallis with outlier 0.005; Kruskal-Wallis without outlier: $\mathrm{p}<0.007$; Florida Escarpment, Fig. 11a; Blake Ridge, Fig. 11b). Mussels with shell lengths $>100 \mathrm{~mm}$ were not infected or only slightly infected with Viral Inclusion III (Fig. 11).

Gill Rickettsia I was present in both species of mussels, but its prevalence varied between habitats. Bathymodiolus puteoserpentis from Logatchev vents had a significantly higher density of Gill Rickettsia I than B. puteoserpentis or $B$. heckerae from the other sites (Tukey's: p < 0.02).

\section{Non-infectious diseases}

Heavy hemocyte infiltration (Fig. 2a) occurred in mussels from all 4 sites (Table 4). Hemocyte infiltration was observed in the majority of mussels
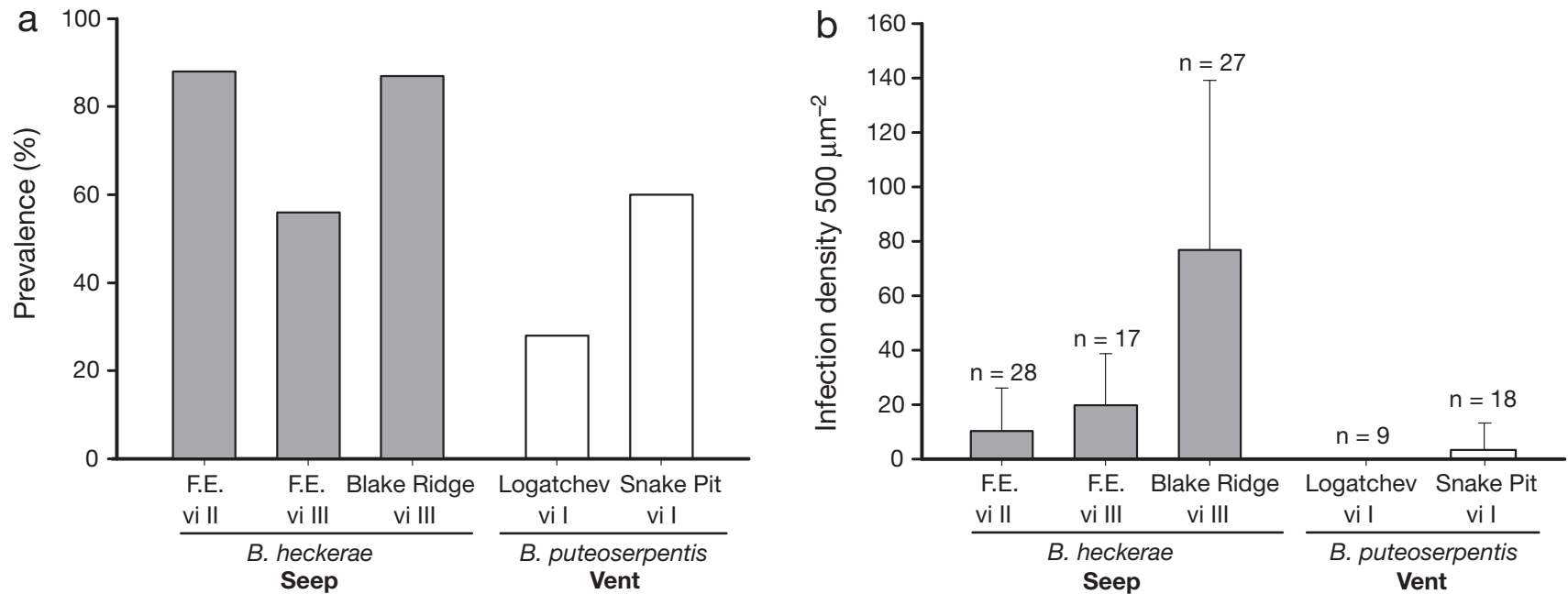

Fig. 10. Bathymodiolus heckerae and B. puteoserpentis. (a) Prevalence of viral-like gut inclusions in mussels (b) density of infection of viral-like gut inclusions $\left(500 \mu \mathrm{m}^{-2}\right)$. F.E.: Florida Escarpment; $\mathrm{n}$ : number of individuals; vi: viral inclusion

Table 4. Bathymodiolus spp. Non-infectious indices of disease and index of gonad development. Prevalence of individuals with hemocyte infiltration and intensity of infiltration $\left(500 \mu^{-2}\right.$ tissue). Number of individuals sampled is shown in parentheses next to site names

\begin{tabular}{|c|c|c|c|c|}
\hline \multirow[t]{2}{*}{ Parameter } & \multicolumn{2}{|c|}{$\begin{array}{c}\text { Bathymodiolus heckerae } \\
\text { Seep sites }\end{array}$} & \multicolumn{2}{|c|}{$\begin{array}{l}\text { Bathymodiolus puteoserpentis } \\
\text { Hydrothermal vent sites }\end{array}$} \\
\hline & Florida Escarpment (32) & Blake Ridge (32) & Logatchev (32) & Snake Pit (30) \\
\hline Prevalence of hemocyte infiltration & $91 \%$ & $97 \%$ & $63 \%$ & $90 \%$ \\
\hline Mean hemocyte infiltration $( \pm \mathrm{SD})$ & $2.2( \pm 1.4)$ & $2.9( \pm 2.0)$ & $2.3( \pm 1.5)$ & $2.8( \pm 1.6)$ \\
\hline Mean gonad development $( \pm \mathrm{SD})$ & $2.3( \pm 0.97)$ & $1.3( \pm 0.70)$ & $3( \pm 1.13)$ & $2.5( \pm 1.10)$ \\
\hline
\end{tabular}



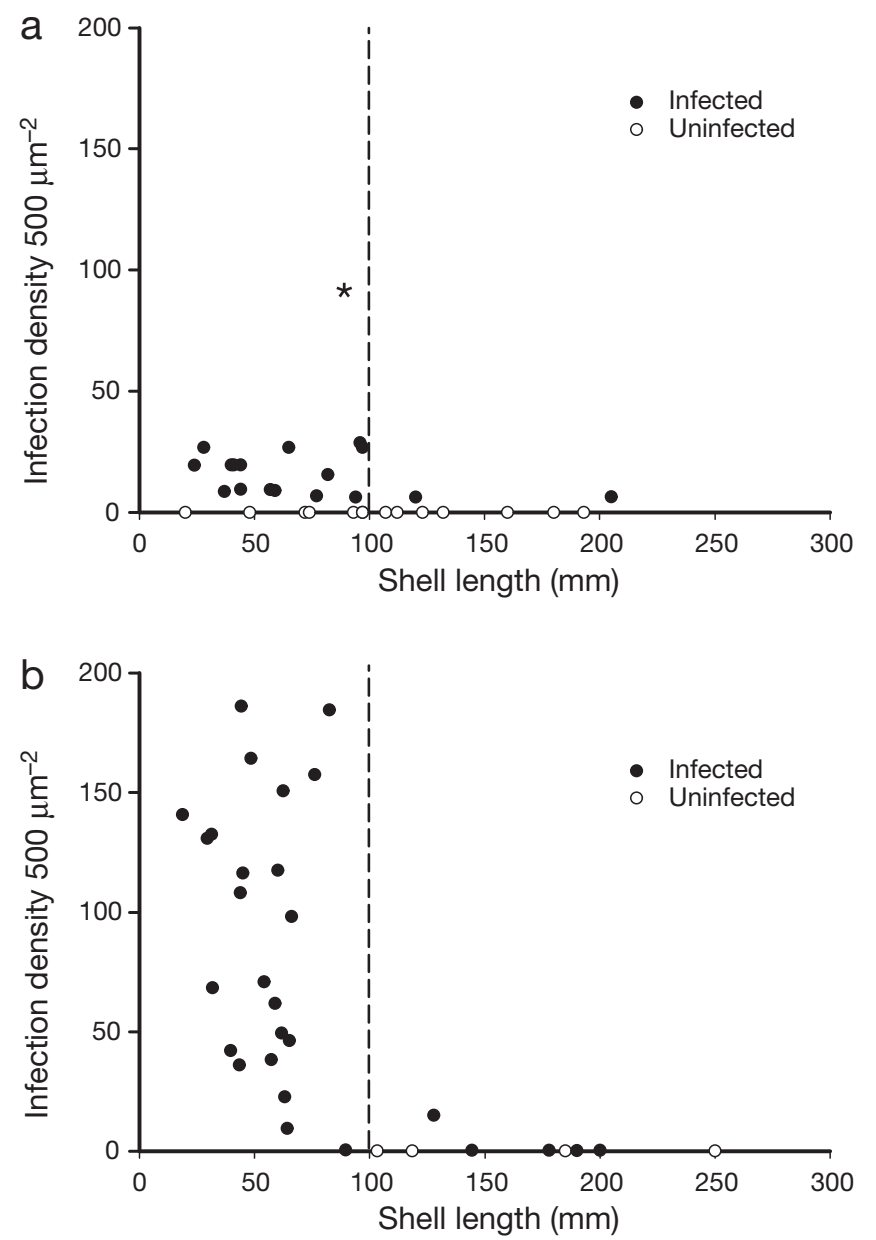

Fig. 11. Bathymodiolus heckerae. Infection density of Viral Inclusion III infections (500 $\mu^{-2}$ tissue) in mussels from (a) Florida Escarpment and (b) Blake Ridge in relation to mussel shell length $(\mathrm{mm})$. *: outlier; dashed line: $100 \mathrm{~mm}$ shell length

(107 of 126) and, in 42 of these mussels, massive hemocyte infiltration resulted in abnormal expansion of blood vessels (Fig. 12). Most hemocytes appeared to be enlarged, with the nuclei displaced to the side of the cells (Fig. 12b). A positive relationship (Pearson's: p < 0.002) was observed between hemocyte infiltration and host length in mussels from all 4 sites.

\section{Index of gonad development}

Gonads of Bathymodiolus heckerae from Florida Escarpment were more developed than those of $B$. heckerae from the Blake Ridge (Kruskal-Wallis: p < 0.001). In B. heckerae from the Florida Escarpment, individuals were more evenly distributed across the

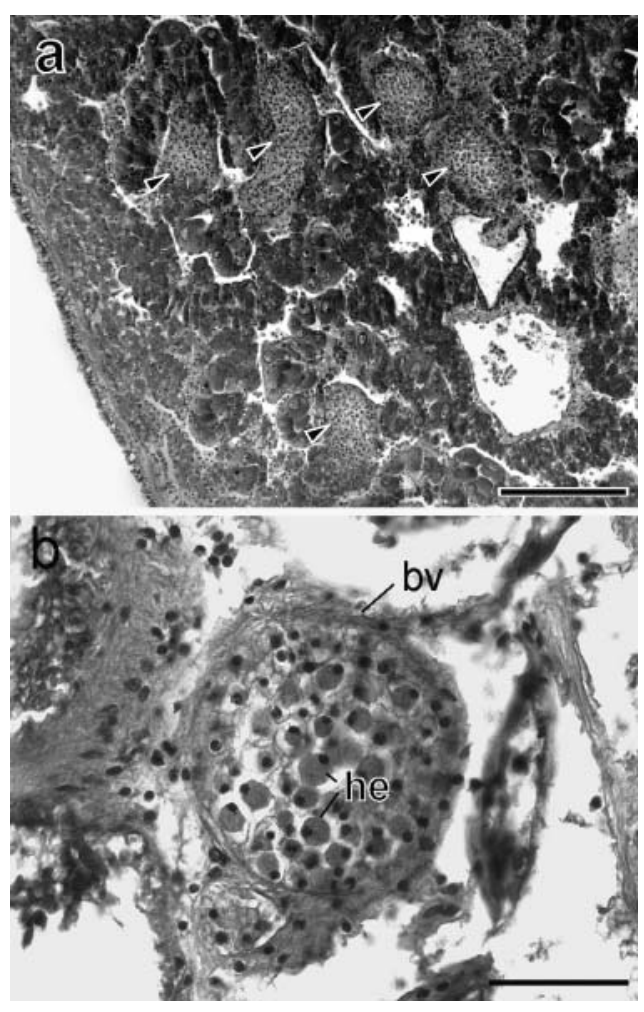

Fig. 12. Bathymodiolus heckerae. (a) Hemocytic infiltration causing enlargement of blood vessels (intensity of 5 ; arrowheads) in visceral mass; scale bar $=200 \mu \mathrm{m}$. (b) Enlarged blood vessel filled with hemocytes; hemocytes are enlarged, with nuclei displaced to side of cells; scale bar $=50 \mu \mathrm{m}$. bv: blood vessel; he: hemocytes

4 categories of gonad development, with only $18 \%$ individuals possessing undifferentiated gonads. In $B$. heckerae from Blake Ridge, $81 \%$ of individuals sampled had undifferentiated gonads. There was a negative correlation between total parasite body burden and degree of gonad development in $B$. heckerae (Pearson's: $\mathrm{p}<0.030$ ); the density of Viral Inclusion III was negatively correlated with gonad development (Pearson's: $p<0.040$ ). There was no difference in gonadal development in B. puteoserpentis from Snake Pit and Logatchev.

\section{Index of endosymbiont density}

In Bathymodiolus puteoserpentis, endosymbiont density was positively correlated with infection density of Gill Rickettsia I (Pearson's: p < 0.020; Fig. 13a). In $B$. puteoserpentis from Snake Pit, endosymbiont density also decreased with greater total body burdens of parasites in individual mussels and with an increase in infection density of Viral Inclusion I (Pearson's: p < 0.020; Fig. 13b). 

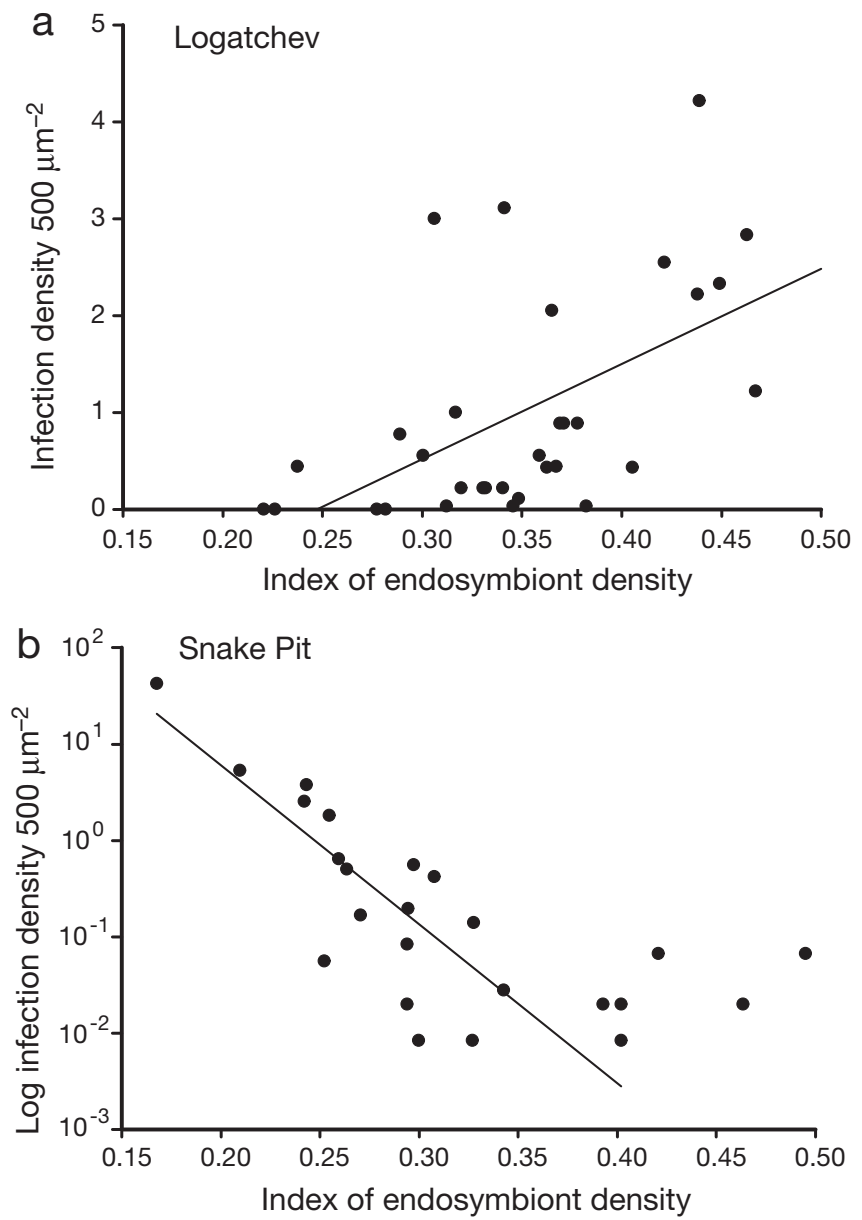

Fig. 13. Bathymodiolus puteoserpentis. Relationships between infection densities and index of endosymbiont density in vent mussels. (a) Infection density of Gill Rickettsia I (500 $\mathrm{\mu m}^{-2}$ tissue) in mussels from Logatchev in relation to index of endosymbiont density; similar relationship was observed in mussels from Snake Pit. (b) Infection density of Viral Inclusion I (500 $\mathrm{m}^{-2}$ tissue) in mussels from Snake Pit in relation to index of endosymbiont density (Pearson's: $\mathrm{p}=0.013$ ); this relationship was not observed in mussels from Logatchev

\section{DISCUSSION}

\section{Parasitism in seep and vent mussels}

We observed 9 different types of parasites in Bathymodiolus heckerae from the seep sites, and only 2 types of parasites in $B$. puteoserpentis from the vent sites. Only 1 type of parasite, Gill Rickettsia I, was common to mussels from both seep and vent habitats. We speculate that the ephemeral and extreme nature of vents may limit colonization and transmission of parasites, resulting in low parasite diversity in vent organisms (viz. Esch et al. 1990, Price 1990). Low diversity of invertebrates at vents compared to seeps has been attributed to the more ephemeral nature of vents
(Craddock et al. 1995, Sibuet \& Olu 1998) and to the potential for greater barriers to invasion of vent habitats due to their more extreme conditions (e.g. elevated metal concentrations, greater sulfide flux; Turnipseed et al. 2003). Other factors might also be implicated in determining the lower parasite diversity at hydrothermal vents. For example, invasion of deep-sea habitats by ancestral, shallow-water host species and their parasites may be a function of proximity to shallow-water sites. The Florida Escarpment and Blake Ridge seep sites, located along the continental margins of eastern North America, are closer to shallow-water habitats than are the Logatchev and Snake Pit vent sites. Seep habitats, with a higher diversity of invertebrate taxa, are more likely to have higher parasite diversity than vent habitats, due to their greater number of potential hosts (Price 1990).

In shallow-water systems, species richness generally decreases as environmental stressors increase (Warwick \& Clarke 1995, Menge \& Branch 2001). Environmental stress, such as pollutants, may affect the physiology of the host organism, thus negatively affecting a host response to disease-causing agents or restricting available habitat within the host for parasitic agents (Laird 1961, Lauckner 1983, Cheng 1988, Winstead \& Couch 1988). Parasites themselves can also be affected by environmental extremes. Deep-sea vent and seep sites contain noxious compounds such as sulfides, brines and metals. These compounds may act as barriers to invasion by parasites and limit infections to microbial agents, as few protozoan and no metazoan parasites other than commensal polychaetes were found in these deep sea mussels.

\section{Pathogenicity}

\section{Viral Inclusion III}

Viral-like infections were the most significant potential disease-causing agents found in the seep and vent mussels. Several lines of evidence, including relationships between mussel size and infection intensities of Viral Inclusion III, tissue destruction associated with Viral Inclusion III, undeveloped gonads in mussels infected by Viral Inclusion III, and in situ observations of extensive mussel mortality, suggest that Viral Inclusion III may be a significant pathogen with a potentially adverse affect on mussel populations at the Blake Ridge seep. Infection by Viral Inclusion III was pathogenic, causing significant damage to the digestive diverticula and connective tissues in the visceral mass. Although bacterial endosymbionts provide most of the nutrition to seep and vent mussels (Felbeck et al. 1981, Cavanaugh 1983, Childress et al. 1986), bathy- 
modiolin mussels retain the ability to filter-feed, which presumably provides some nutrition to the mussels (Le Pennec \& Hily 1984, Page et al. 1991). Viruses that form intranuclear inclusion bodies, such as those observed for Viral Inclusion III, can result in reduced food uptake in bivalves due to necrosis within the digestive tract (see Lauckner 1983). The high prevalence of mussels with undifferentiated gonads from Blake Ridge may have been a result of castration by Viral Infection III or resorption of gonads by an infected host, which is a common response of molluscs to disease (Lauckner 1983).

Several patches of empty valves have been observed in mussel populations from Blake Ridge, suggesting that mass mortalities have occurred at this site (Van Dover et al. 2003). While mortality could not be attributed to a specific cause, the valves were relatively uniform in size, suggesting a common cause of death. Mortality was attributed to shifting foci of seepage (Van Dover et al. 2003), but the pathogenicity of Viral Inclusion III suggests an alternative hypothesis, namely that viral infection may have contributed to mortality. Mussels with shell lengths $>100 \mathrm{~mm}$ were either lightly infected or uninfected with Viral Inclusion III, and may represent a subset of the population that was immune to infection or strong enough to overcome the infection. Alternatively, Viral Inclusion III may be an opportunistic parasite infecting stressed hosts.

\section{Hemocytic infiltration}

Heavy infiltration by enlarged hemocytes was observed in the majority of mussels sampled. The predominant mechanism of molluscan internal defense involves phagocytosis by circulating hemocytes (Pipe \& Coles 1995); and infiltration by hemocytes is part of the immune response to parasitic infection in molluscs (Quayle 1969, Lauckner 1983, Pipe \& Coles 1995). The enlarged hemocytes seen in Bathymodiolus heckerae and $B$. puteoserpentis may be abnormal and may impair host immune functions. The extreme infiltration by hemocytes into tissues and blood vessels was comparable to that observed in diseased, shallow-water bivalves (reviewed in Lauckner 1983). Although hemocyte infiltration can increase with parasitic infection, no correlation was observed between parasite infection densities and hemocyte infiltration in $B$. heckerae or $B$. puteoserpentis. While hemocytes are important in molluscan internal defense, heavy hemocyte infiltration can hinder the normal flow of hemolymph, give rise to a reduction of host tissues needed for vital functions, and has been suggested as a possible cause of mass mortalities (Lauckner 1983, Villalba et al. 1997, Lee et al. 2001).

\section{Prevalences of parasites}

Of the parasite types observed in Bathymodiolus heckerae (Gill Rickettsia I \& II, gill ciliates, gill 'rosettes', and gut chlamydia) $50 \%$ were similar to parasites present in mussels (Bathymodiolus sp.) of relatively shallow (550 to $650 \mathrm{~m}$ ) hydrocarbon seeps (Powell et al. 1999), and all but the gill rosettes are similar to common parasites found in coastal-zone mussels (Kim et al. 1998). Parasites resembling gill rosettes occur in the shallow-water lucinid clam Loripes lucinalis, which also hosts chemoautotrophic, endosymbiotic bacteria in its gills (Johnson \& Pennec 1995, Powell et al. 1999). Trematodes (Bucephaluslike), which were the most pathogenic parasite observed by Powell et al. (1999) and which can be common in intertidal mussels (Lauckner 1983, Kim et al. 1998, Montaudaouin et al. 2000), were entirely absent from Bathymodiolus heckerae and B. puteoserpentis from the deeper vents and seeps. Trematodes were also absent from limpets from deep-sea hydrothermal vents and a deep-sea seep site (Terlizzi et al. 2004, this issue). Larval trematodes have a high host-specificity and use molluscs as their first intermediate hosts (see Lauckner 1983, Mouritsen et al. 1997). Transmission and infection by trematodes are affected by locality, season and host (Lauckner 1983, Montaudaouin et al. 2000). The absence of trematodes in this study could be the result of factors such as depth, susceptibility to heavy-metal toxicity in trematode larval stages, or the lack of suitable intermediate and definitive hosts.

\section{Polychaetes}

Polychaetes are commonly found within the mantle cavities and between the gills of bathymodiolin mussels (Van Dover et al. 1999), but their true relationship with the host mussel is unknown. Gill flatworms (e.g. Urastoma cyprinae) are also common inhabitants of mantle cavities in coastal mussels (Villalba et al. 1997). Flatworms can disrupt the structure of gill filaments, cause necrosis of gill tissue, and thereby reduce the feeding capacity of the host, resulting in loss of condition. From these observations, Villalba et al. (1997) concluded that the flatworms were parasitic. Both the polynoid Branchipolynoe seepensis and the nautliniellid Laubierus mucronatus polychaetes found in vent and seep mussels cause minor tissue damage to the gills and displacement of gill filaments, but there is no strong evidence for a detrimental effect on host condition. This is consistent with observations of Fisher et al. (1988), who found that a species of commensal polynoid polychaete in mussels at the Rose Garden hydrothermal vent (Galapagos Spreading Center; 
eastern Pacific Ocean) did not cause gross lesions in soft tissues of the infected mussels. The polychaetes probably consume bacterial-laden mucus or pseudofeces, or free-living bacteria rather than tissues of the host mussel.

In summary, parasite burdens were greater in mussels at seeps than at vents. In some instances, parasites may affect reproductive output and overall health of the mussel populations, as observed in shallow-water bivalve populations. We suggest that infection by Viral Inclusion III influences population dynamics of Bathymodiolus heckerae at the Blake Ridge seep site, possibly causing widespread mortalities in juvenile mussels. Mussels from both seep and vent sites suffered from severe hemocytic infiltration by enlarged hemocytes. Hemocytic infiltration may be a symptom of disease or it may be an independent agent of mortality. How parasitic infections and hemocytic conditions affect individual mussels and the invertebrate communities associated with deep-sea mussel beds remains to be determined. Therefore, parasitological studies are a necessary addition to the more traditional ecological approaches used, in order to obtain an accurate representation of the factors affecting community structure.

Acknowledgements. We thank M. Forsyth for his valuable contributions to this project. We also thank L. Calvo, R. Crockett, and S. Ford for their help identifying parasites and J. Scott and J. Thomas for their advice. We are grateful to the 'Alvin' group and the captain and crew of the RV 'Atlantis' for their help in sample collection. This work was funded in part by a Lerner Gray Fund grant from the American Museum of Natural History and a Minor Research grant from The College of William \& Mary to M.E.W. We also acknowledge NSF grants OCE98-18550 and OCE99-82995 and support from NOAA's National Undersea Research and Ocean Exploration Programs to C.L.V.D.

\section{LITERATURE CITED}

Anderson RM (1978) The regulation of host population growth by parasite species. Parasitology 76:119-157

Anderson RM, May RM (1978) Regulation and stability of host-parasite population interactions. I. Regulatory processes. J Anim Ecol 47:219-247

Batuyev BN, Krotov AG, Markov VF, Cherkashev GA, Krasnov SG, Lisitsyn YD (1994) Massive sulphide deposits discovered and sampled at $14^{\circ} 45^{\prime}$ N, Mid-Atlantic Ridge. BRIDGE Newsl 6:6-10

Calvo-Ugarteburu G, McQuaid CD (1998) Parasitism and invasive species: effects of digenetic trematodes on mussels. Mar Ecol Prog Ser 169:149-163

Cavanaugh CM (1983) Symbiotic chemoautotrophic bacteria in marine invertebrates from sulfide-rich habitats. Nature 302:58-61

Cheng TC (1988) In vivo effects of heavy metals on cellular defense mechanisms of Crassostrea virginica: total and differential cell counts. J Invertebr Path 51:207-214

Childress JJ, Fisher CR, Brooks JM, Kennicutt II MC, Bidigare
R, Anderson A (1986) A methylotrophic marine molluscan symbiosis: mussels fueled by gas. Science 233:1306-1308

Clarke KR, Gorley RN (2001) PRIMER v5: User manual/ tutorial. PRIMER-E Ltd, Plymouth

Craddock C, Hoch WR, Gustafson RG, Lutz RA, Hashimoto J, Vrijenhoek RC (1995) Evolutionary relationships among deep-sea mytilids (Bivalvia: Mytilidae) from hydrothermal vents and cold-water methane/sulfide seeps. Mar Biol 121: 477-485

Esch GW, Shostak AW, Marcogliese DJ, Goater TM (1990) Patterns and processes in helminth parasite communities: an overview. In: Esch GW, Bush A, Aho J (eds) Parasite communities: patterns and processes. Chapman \& Hall, New York, p 1-19

Felbeck H, Childress JJ, Somero GN (1981) Calvin-Benson cycle and sulfide oxidation enzymes in animals from sulfide rich habitats. Nature 293:291-293

Fernley PW, Moore MN, Lowe DM, Donkin P, Evans S (2000) Impact of the Sea Empress oil spill on lysosomal stability in mussel blood cells. Mar Environ Res 50:451-455

Fisher CR, Childress JJ, Arp AJ, Brooks JM and 11 others (1988) Microhabitat variation in the hydrothermal vent mussel, Bathymodiolus thermophilus, at the Rose Garden vent on the Galapagos Rift. Deep-Sea Res Part I 35: 1769-1791

Hayak LC, Buzas MA (1997) Surveying natural populations. Columbia University Press, New York

Humason GL (1972) Animal tissue techniques. WH Freeman \& Company, San Francisco, CA

Johnson MA, Pennec M (1995) Association between the mollusc bivalve Loripes lucnalis and a Chlamydia-like organism, with comments on its pathogenic impact, life cycle and possible mode of transmission. Mar Biol 123:523-530

Karson JA, Brown JR (1988) Geologic setting of the Snake Pit hydrothermal site: an active vent field on the Mid-Atlantic Ridge. Mar Geophys Res 10:91-107

Kautsky N (1982) Growth and size structure in a Baltic Mytilus edulis population. Mar Biol 68:117-133

Kim Y, Powell EN, Wade TL, Presley BJ, Sericano J (1998) Parasites of sentinal bivalves in the NOAA Status and Trends Program: distribution and relationship to contaminant body burden. Mar Pollut Bull 37:45-55

Laird M (1961) Microecological factors in oyster epizootics. Can J Zool 39:449-485

Lauckner G (1983) Chapter 14. Disease of Mollusca: Bivalvia. In: Kinne O (ed) Diseases of marine animals, Volume II: Introduction and Bivalvia to Scaphopoda. Biologische Anstalt Helgoland, Hamburg, p 477-879

Lee MK, Choa BY, Lee SJ, Kanga JY, Jeonga HD, Huhb SH, Huha MD (2001) Histopathological lesions of Manila clam, Tapes philippinarum, from Hadong and Namhae coastal areas of Korea. Aquaculture 201:199-209

Le Pennec M, Hily A (1984) Anatomie, structure et ultra structure de la branchie d'un Mytilidae des sites hydrothermaux du Pacifique Oriental. Oceanol Acta 7:517-523

Le Pennec M, Donval A, Herry A (1990) Nutritional strategies of the hydrothermal ecosystem bivalves. Prog Oceanogr 24:71-80

MacDonald IR, Guinasso ML Jr, Reilly JF, Brooks JM, Callender WR, Gabrielle SG (1990) Gulf of Mexico hydrocarbon seep communities. VI. Patterns in community structure and habitat. Geo-Mar Lett 10:244-252

Margolis L, Esch GW, Holmes JC, Kuris AM, Schad GA (1982) The use of ecological terms in parasitology (report of an ad hoc committee of the American Society of Parasitologists). J Parasitol 68:131-133

Menge BA, Branch GM (2001) Rocky intertidal communities. 
In: Bertness MD, Gaines SD, Hay ME (eds) Marine community ecology. Sinauer, Sunderland, MA, p 221-251

Montaudouin X de, Kisieleeshki I, Bachelet G, Desclaux C (2000) A census of macroparasites in an intertidal bivalve community, Arcachon Bay, France. Oceanol Acta 23: $453-468$

Mouritsen KN, Jensen T, Jensen KT (1997) Parasites on an intertidal Corophium-bed: factors determining the phenology of microphallid trematodes in the intermediate host population of the mud-snail Hydrobia ulvae and the amphipod Corophium volutator. Hydrobiologia 355:61-70

Page HM, Fiala-Médioni A, Fisher CR, Childress JJ (1991) Experimental evidence for filter-feeding by the hydrothermal vent mussel, Bathymodiolus thermophilus. Deep-Sea Res Part I 38:1455-1461

Paull CK, Hecker B, Commeau R, Freeman-Lynde RP and 6 others (1984) Biological communities at the Florida escarpment resemble hydrothermal vent taxa. Science 226:965-967

Pipe RK, Coles JA (1995) Environmental contaminants influencing immune function in marine bivalve mulluscs. Fish Shellfish Immunol 5:581-595

Powell EN, Barber RD, Kennicutt II MC, Ford SE (1999) Influence of parasitism in controlling the health, reproduction and PAH body burden of petroleum seep mussels. DeepSea Res Part I 46:2053-2078

Price PW (1990) Host populations as resources defining parasite community organization. In: Esch GW, Bush A, Aho J (eds) Parasite communities: patterns and processes. Chapman \& Hall, New York, p 21-40

Price PW, Westoby M, Rice B, Atstatt PR, Fritz RS, Thompson JN, Mobley K (1986) Parasite mediation in ecological interactions. Annu Rev Ecol Syst 17:487-505

Quayle DB (1969) Pacific oyster culture in British Columbia. Bull Fish Res Board Can 169:1-192

Raulfs EC, Macko SA, Van Dover CL (in press) Tissue and symbiont condition of mussels (Bathymodiolus thermo-

Editorial responsibility: Albert Sparks, Seattle, Washington, USA philus) exposed to varying levels of hydrothermal activity. J Mar Biol Assoc UK

Sibuet M, Olu K (1998) Biogeography, biodiversity, and fluid dependence of deep-sea cold-seep communities at active and passive margins. Deep-Sea Res Part II 45:517-567

Stevens A (1990) The haematoxylins. In: Bancroft JD, Stevens A (eds) Theory and Practice of histological techniques. Churchill Livingstone, New York, p 107-118

Terlizzi CM, Ward ME, Van Dover CL (2004) Observations on parasitism in deep-sea hydrothermal vent and seep limpets. Dis Aquat Org 62:17-26

Turnipseed M, Knick KE, Lipcius RN, Dreyer J, Van Dover CL (2003) Biodiversity hotspots at cold seeps? Ecol Lett 6: $518-523$

Van Dover CL (2000) The ecology of deep-sea hydrothermal vents. Princeton University Press, Princeton, NJ

Van Dover CL, Trask J, Gross J, Knowlton A (1999) Reproductive biology of free-living and commensal polyniod polychaetes at the Lucky Strike hydrothermal vent field (Mid Atlantic Ridge). Mar Ecol Prog Ser 181:201-214

Van Dover CL, Aharon P, Bernhard JM, Caylor E and 15 others (2003) Blake Ridge methane seeps: characterization of a soft-sediment, chemosynthetically based ecosystem. Deep-Sea Res Part I 50:281-300

Villalba A, Mourelle SG, Carballal MJ, Lopez C (1997) Symbionts and disease of farmed mussels Mytilus galloprovincialis throughout the culture process in the Rias of Galicia (NW Spain). Dis Aquat Org 31:127-139

Warwick RM, Clarke KR (1995) New 'biodiversity' measures reveal a decrease in taxonomic distinctness with increasing stress. Mar Ecol Prog Ser 129:301-305

Winstead JT, Couch JA (1988) Enhancement of protozoan pathogen Perkinsus marinus infections in American oysters Crassostrea virginica exposed to the chemical carcinogen n-nitrosodiethylamine (DENA). Dis Aquat Org 5:205-213

Submitted: July 30, 2003; Accepted: March 18, 2004 Proofs received from author(s): October 26, 2004 